\title{
Högskolan har ett ansvar att aktivt verka för humanitära och demokratiska värderingar, social och ekonomisk rättvisa
}

Högskolan tar ett alltför litet ansvar för att aktivt verka för samhällets i lag fastslagna värderingar, inte minst för rättvisa. En rädsla för att inte synas vara vetenskapligt objektiv och för att propagera för politiska värderingar borde kunna ersättas av att all utbildning tydligt och ständigt både bygger på och prövar grundläggande värderingar. Bland dessa måste finnas frågor om vad som är ett gott liv och vad som är ett gott samhälle.

Värdeorden i denna princip känns igen från inledningen till Sveriges grundlag, Regeringsformens andra paragraf. Där står det att: "Den offentliga makten ska utövas med respekt för alla människors lika värde och för den enskilda människans frihet och värdighet /.../ Det allmänna ska verka för att demokratins idéer blir vägledande inom samhällets alla områden/.../ Det allmänna ska verka för att alla människor ska kunna uppnå delaktighet och jämlikhet i samhället.” Om man läser vidare i lagboken ser man att en av Högskolelagens portalparagrafer, paragraf 5, klär in också rättviseidealet som en förutsättning för ett långsiktigt hållbart samhälle: "Högskolorna skall i sin verksamhet främja en hållbar utveckling som innebär att nuvarande och kommande generationer tillförsäkras en hälsosam och god miljö, ekonomisk och social välfärd och rättvisa.”

Dessa värderingar är alltså så allmänt accepterade att de utgör grund för svensk lagstiftning. Det borde därför rimligen inte råda någon större diskussion

How to cite this book chapter:

Casson, A 2015 Högskolans ansvar: Principer för utveckling av den högre utbildningen.

London: Ubiquity Press. DOI: http://dx.doi.org/10.5334/bap.e License: CC-BY 3.0 
om själva målen: humanitära och demokratiska värderingar, social och ekonomisk rättvisa. Detta trots att det allmänna, i form av regering och Riksdag, ofta tycks stifta lagar och genomföra reformer som direkt eller indirekt motverkar både jämlikhet och rättvisa mellan samhällsgrupper. Men hur ska vi tolka och tillämpa begreppen inom högskolan och hur skulle högskolan kunna aktivt verka för dem?

Flera av dessa grundprinciper för högskolans verksamhet utgör omistliga delar i de centrala handlingsförmågorna jag redan nämnt. Men kanske en av de mest förvånande formuleringarna i lagtexten är att den tar så tydlig ställning för social och ekonomisk rättvisa. Man tänker sig att rättvisa innebär att samhällets goda ska fördelas på ett någorlunda rimligt sätt mellan medborgarna, inte på grundval av vem som är starkast, eller smartast eller fräckast.

\section{Läskflaskan och vattenpasset}

John Rawls var en av det senaste århundradets viktigaste tänkare när det gäller grunderna för rättvisa. Han hävdar i sin En teori om rättvisa (1971) att det finns två grundläggande principer för rättvisa:

1. rätten till så mycket jämlik frihet som tillåter också andra att njuta den

2. social och ekonomisk ojämlikhet måste grundas på att den ger

a. lika möjligheter för alla

b. de största fördelarna till de sämst ställda

När det gäller själva fördelningen, menar han, bör den göras efter en princip som i och för sig mina barn tillämpade när de var små och skulle dela på en liten flaska läsk: du häller, jag väljer. Det vill säga att den som fördelar det goda inte själv i förväg vet vilken del som kommer att tillfalla henne. Du vet inte i förväg om du kommer att sluta som rik eller fattig, man eller kvinna, chef eller underlydande och fördelningen bör ske på det mest rättvisa sättet du kan tänka ut. Rawls kallar detta för the veil of ignorance, okunnighetens slöja, som bör täcka alla våra särintressen, alla våra tyckanden och preferenser, för att våra vägval och beslut ska kunna styras av största möjliga rättvisa.

Jag vet inte, men jag tror att många lärare i högskolan är avvaktande när det gäller att aktivt verka för rättvisa genom sin forskning och undervisning. Det är som om man väljer sida då, och eftersom man bör vara oväldig tjänsteman och inte otillbörligen påverka studenter i vad som kan uppfattas som politiska frågor, undviker man sådana frågor. Om man istället ständigt återkommer i sin undervisning, både genom innehållet och former, till dessa grundläggande principer, verkar man aktivt för dem. Det krävs att utbildningsplaner och kursplaner visar hur principerna kommer till uttryck; det krävs att läraren själv har tagit ställning och är kapabel och beredd att leda samtal om hur området för 
diskussion förhåller sig till sådana rättviseprinciper. De griper in i varje samhällsområde som vi undervisar eller forskar inom.

Om man accepterar John Rawls grundläggande utgångspunkter om rättvisa och om samhället strävar någorlunda i den riktningen, leder det rimligen, över tid, till ett mera jämlikt samhälle, ett samhälle med ett mindre gap mellan fattiga och rika. ${ }^{55}$ Och om man ser till västvärldens utveckling under moderniteten, det vill säga de senaste 300-400 åren sedan upplysningen förde med sig demokratiseringsidéerna, avsättandet av såväl kungarnas som kyrkans makt, individens ökande frihet genom det rationella förnuftet, så har också jämlikheten stadigt ökat. Likhet inför lagen, slaveriets avskaffande, rösträtt för alla män och kvinnor, både de som äger och de som inte äger, skolor för alla, fritt tillgänglig hälso- och sjukvård, socialförsäkringar, lagstiftning mot diskriminering listan kan göras lång på reformer som alla bidragit till en ökande jämlikhet de senaste seklerna. En förutsättning för reformerna har varit en viss ekonomisk standard, att summan av alla människors arbete har räckt till, inte bara för kläder och mat och varma hus att bo i, utan för att skapa alla de samhällsinstitutioner och bekvämligheter och framförallt all den trygghet och tillit som behövs för ett gott liv. En ständig ekonomisk tillväxt var nödvändig för att åstadkomma de materiella förutsättningarna för ett gott liv. Men idag samlas en allt tyngre bevisning för att planeten inte tål en fortsatt ohämmad tillväxt, argument som jag utvecklar vidare i andra delar av mitt resonemang. Och när man väl kommit över en viss nivå, leder inte fler materiella tillgångar till ett bättre liv. Vad som påverkar de flesta människors liv allra mest är hur tillgångarna fördelas i ett samhälle.

Vid första anblicken kan ett sådant påstående kanske verka överdrivet. Kan det verkligen vara så? Bygger det inte snarare på en politisk uppfattning? Richard Wilkinson och Kate Pickett har samlat en överväldigande mängd uppgifter från världens, framförallt rikare, länder om hur inkomstfördelning påverkar livskvalitet. ${ }^{56}$ Bevisen, byggda på de mest tillförlitliga underlagen som kan tas fram, är fullständigt förkrossande. Ju mera jämlikt ett land är, desto bättre mår alla invånare. Den som har färdats i Sydafrika eller något annat land med extrema skillnader mellan villkoren för fattiga och rika har sett hur villorna måste omges med taggtråd och höga murar och hört om den rädsla som finns för att röra sig utomhus på kvällstid. Men Wilkinson och Pickett visar i sin framställning hur på område efter område de mera jämlika länderna kan erbjuda sina medborgare ett bättre liv: livslängd, fysisk hälsa, mental hälsa, droganvändning, fetma, utbildningsnivåer, våld i samhället, antalet fångar. På varje område finns betydande skillnader mellan samhällen, och det är alltid de samhällen med mindre inkomstspridning som klarar sig bäst. I USA sitter 600 människor i fängelse för varje $100000 \mathrm{i}$ befolkningen. I Japan, landet med

\footnotetext{
55 "The priority of the social and economic order is, in other words, to maximise the minimum." (Rawls 1971, s128)

56 Wilkinson \& Pickett 2010.
} 
minst inkomstspridning, är motsvarande siffra 40. I de nordiska länderna ligger siffran kring 50 och sjunker för närvarande ganska snabbt. Dessutom visar siffrorna stora skillnader mellan delstaterna i USA. De med störst inkomstspridning, Louisiana och Texas till exempel, är också de med flest fångar, uppemot sex gånger fler än i Minnesota. Det är också de stater som har avskaffat dödsstraffet som har lägst andel fångar. Skälen är inte framförallt skillnader i antalet begångna brott, visar det sig, utan i attityder till bestraffning. De länder och stater som har störst inkomstskillnader är också de där upplevelsen av "vi" och "dem" är störst, där tilliten mellan människor är minst och där de populära mediernas rop på strängare straff har påverkat lagstiftande politiker mer än de förnuftiga skälen som visar att fängelsestraff inte påverkar brottsfrekvenser annat än negativt. ${ }^{57}$ Även om just fängelsestraffen inte i första hand speglar brottsfrekvensen, är också antalet våldsbrott i hög grad påverkat av inkomstfördelning i ett samhälle.

Hälsostatistiken är lika entydig. Det är inte framförallt hur mycket pengar ett samhälle lägger ut på sjukvård i snitt per medborgare som är avgörande utan hur resurserna fördelas mellan befolkningen. Wilkinson och Pickett visar att ett barn som föds i USA, där man i snitt lägger ut 6000 dollar per år och invånare på hälsovård, har en förväntad livslängd som är 1, 2 år kortare än ett barn som föds i Grekland, där hälsovården får hälften så mycket resurser per invånare men fördelar dem långt jämnare över hela befolkningen. En del i detta är också att spädbarnet i USA har 40 \% högre risk att inte överleva sitt första år än spädbarnet i Grekland. Forskningsresultaten de samlar är övertygande. Redan 1996 skrev redaktörerna för British Medical Journal att, "Den stora bilden är att det avgörande för dödlighet och hälsa i ett samhälle är inte så mycket det samhällets totala välstånd utan mer hur välståndet fördelas. Ju jämnare rikedomar fördelas, ju bättra hälsa får ett samhälle." ${ }^{58}$ Sedan 1996 har inte inkomstskillnaderna minskat, vare sig i UK eller i Sverige. Naturligtvis finns stora skillnader mellan olika sjukdomar och olika dödsorsaker - cancer drabbar alla lika medan dödlighet genom hjärtsjukdomar eller mord drabbar de fattiga i långt högre grad - men genomgående dör fattiga långt tidigare än rika. Orsakerna står att finna, enligt de källor som Wilkinson och Pickett samlat, i psykosociala faktorer, framförallt långvarig stress orsakad av känslor av misslyckande, otillräcklighet och missnöje med sig själv. Vad som kanske är mer förvånande är att även de rika kan förvänta sig ett längre liv i ett mera jämlikt samhälle. Sammanhållning och tillit i ett samhälle tycks vara avgörande för hälsa och livslängd. Att hälsonivåer i ett samhälle påverkas av ojämlikhet i inkomstfördelning och inte bara kan förklaras av välstånd eller fattigdom $\mathrm{i}$ absoluta termer har visats

\footnotetext{
57 Ibid, s 145-156.

58 "The big idea is that what matters in determining mortality and health in a society is less the overall wealth of that society and more how evenly that wealth is distributed. The more equally wealth is distributed the better the health of that society." British Medical Journal 1996, 312 (7037) Citerat i Wilkinson \& Picket 2010, s 81
} 
gång efter annan i olika undersökningar publicerade i världens mest ansedda tidskrifter. I en relativt ny sammanställning i British Medical Journal kommer författarna fram till att uppemot vart tionde dödsfall mellan åldrarna 15 och 60 år, eller i absoluta termer 1,5 miljoner dödsfall, skulle kunna förhindras genom att minska ojämlikhet enbart i OECD-länderna. ${ }^{59}$

Jag ska inte referera hela vidden av Wilkinson och Picketts forskningsgenomgång men deras resonemang när det gäller just utbildningsfrågor är särskilt relevant för flera av mina principer. På motsvarande sätt som alla andra områden de undersöker, visar resultat av forskningsgenomgången att mindre jämlika länder får sämre utbildningsresultat. Än en gång är det inte det totala välståndet i ett land som är avgörande utan hur välståndet är fördelat. Sammanhållning och tillit mellan människor är sämre där inkomstskillnaderna är större. Detta påverkar, visar forskningsgenomgången entydigt, både mental och fysisk hälsa, skilsmässor, våld inom familjen med flera faktorer som alla påverkar barnets utveckling. Det gör också naturligtvis samhällets sätt att erbjuda och finansiera förskolor. Men själva förväntningarna på sig själv och hur man blir sedd påverkas av jämlikheten i ett samhälle. Där vi förväntar oss att bli sedda som underlägsna verkar det som om vår förmåga försämras, sammanfattar Wilkinson och Pickett ett antal undersökning som de refererar. ${ }^{60} \mathrm{Vi}$ lär oss bäst i miljöer där vi känner oss trygga och där det finns en förväntan på att vi ska lyckas. Upplever vi stress, hopplöshet eller hot försämras minnet och inlärningsförmågan.

Argumenten är fullständigt övertygande. Varje rimlig tolkning av bevisen som samlats av vetenskapssamhället $i$ de strängast granskade forskningstidskrifterna måste peka på behovet av större ekonomisk jämlikhet. Det har framförts en del kritik av Wilkinson och Picketts arbete, inte bara i den engelskspråkiga världen, utan även i häften utgivna av olika intresseorganisationer i de flesta länder där boken publicerats, bland andra Sverige, vilket i och för sig antyder vilken genomslagskraft The Spirit Level har haft. Den kritiken bemöter författarna i en andra upplaga av boken från 2010. När jag har läst alltihopa och efter min bästa förmåga jämfört argumenten kan jag inte finna annat än att det står fullständigt klart att mer jämlika samhällen skapar ett bättre liv för människor. Vilka program politikerna än väljer att föra fram och vilka partier väljarna än väljer att rösta på så menar jag att vi som akademiska lärare har skyldighet att sprida och diskutera dessa forskningsresultat. Var och en får dra slutsatser för sitt eget politiska ställningstagande men det är både oärligt och oansvarigt av oss inom högskolan att förtiga eller förminska betydelsen av sådana resultat. De ligger i mittfåran av vad våra professionella utbildningar sysslar med. Skulle inte vi inom högskolan aktivt verka för att förändra samhället genom våra utbildningar? Blir det en otillbörlig politisk handling att

${ }^{59}$ Kondo N. et al 'Income inequality, mortality, and self-rated health: meta-analysis of multi-level studies'. British Medical Journal 2009;339.

${ }^{60}$ Wilkinson \& Pickett 2010, s 113. 
belysa sådana forskningsresultat i våra yrkesutbildningar till lärare, sjuksköterska, ingenjör, ekonom, socionom, när folkhälsa, utbildningsresultat, sociala missförhållanden, brottslighet, drogberoende, alla påverkas i så hög grad av inkomstfördelningen i ett samhälle? Jag menar snarare att det är en otillbörlig politisk handling att låta bli. Akademisk hederlighet och ansvar kräver att vi bidrar till en förbättring, annars bidrar vi till en försämring.

\section{Vad är ett gott liv?}

Det kan tänkas att det inte bara är rädsla för att synas ta sida i politiken som gör att akademiska lärare och akademiska institutioner så ogärna uttalar sig om samhällsförhållanden eller ogärna vill framstå som förebilder i sina åsikter och ställningstaganden. Det kan tänkas att det också är avsaknad av en sammanhängande och konsekvent moral. Jag menar förstås inte att akademiker skulle vara omoraliska, utan att vi åtminstone i västvärlden är en del av en värld som sedan århundraden betraktat moral som ett område för diskussion och tyckanden, där man kan plocka bitar här och där utan att ha riktigt klart för sig hur det hela hänger ihop. Helt enkelt, kanske, därför att det inte hänger ihop. Filosofen Alasdair Macintyre visar i sin After Virtue från 1981 på ett slående sätt hur våra dagars argument för och emot krig, för och emot abort eller för och emot privata skolor och hälsovård aldrig kan avgöras, helt enkelt därför att skälen de olika sidorna anför inte går att mäta med varandra. De lider alltså, med en term som MacIntyre lånar från vetenskapsteorin, av begreppslig inkommensurabilitet. I det sistnämnda fallet med privata skolor och sjukhus - som jag återkommer längre fram under en annan princip - står kravet på jämlikhet och allas rättigheter å ena sidan mot kravet på frihet för var och en att välja fritt om man vill starta en skola eller om man vill uppsöka privat läkarvård. Vem ska avgöra vad som är viktigast, frihet eller jämlikhet? Du själv, förstås, tänker vi. Du har friheten att tycka vad du vill och förmodligen har du redan bestämt dig innan du ger dig in i diskussionen. Och eftersom det inte finns en gemensam grund för diskussionen är den enda utvägen att man höjer rösten! Emotivist, kallas man av filosoferna om man anser att moral är en fråga om tycke och smak, och nog är många av oss inom akademin emotivister idag. Få tänker ens att det kunde eller borde finnas något sammanhängande moralsystem, därför att det var så länge sedan det försvann, åtminstone utanför trossamfunden. Hos Aristoteles fanns dock ett sådant sammanhängande system av dygder och det är till honom som MacIntyre vänder sig för att finna en grund för sin dygdetik. ${ }^{61}$ Dygd är dock inte något riktigt bra ord på svenska för vad Aristoteles vill uttrycka och vad hans samtid förstod med det grekiska arete. Dygd har alldeles

${ }^{61}$ Min sammanfattning gör knappast rättvisa åt Macintyres resonemang, som kan läsas i sin helhet i det andra kapitlet av After Virtue, "The Nature of Moral Disagreement Today and the Claims of Emotivism". (Macintyre 1981 s 7-25) 
för många övertoner av gammaldags strängt moraliserande och förtryck. Den svenska översättaren av Aristoteles Nichomachiska etiken, där det mesta av hans morallära finns, Mårten Ringbom, föredrar "det förtjänstfulla", "det förträffliga" och liknande. ${ }^{62}$ Och som det yttersta målet för människan i Aristoteles praktiska, tillämpade moralsystem finns eudaimonia, som oftast översatts som "lycka" men som i så fall är en väldigt speciell sorts lycka, mera förbunden med att leva ett gott och riktigt liv. Det kanske räcker här att nämna att Aristoteles sade att den lyckan inte är förbunden med pengar, ära eller njutning, så förstår man bättre vad han är ute efter.

Men det finns ingen grundöverenskommelse i vår moderna värld med dess liberala värderingar, som också innefattar friheten att tycka som man vill och att alla tyckanden är lika giltiga, om att eudaimonia eller ett gott liv är slutmålet och måttstocken för våra handlingar. Det är på grund av detta som jag undrar om inte vi, som goda akademiker och demokrater, gärna intar en neutral ställning i moralfrågor. Jag tror inte heller att jag är ensam om att vara lite feg i sådana sammanhang; skyddar mig bakom neutralitetens och emotivismens mask för att inte ge mig in på sådant jag inte kan. Visst - det är viktigt, men då kan man överlämna frågan till etikavdelningen inom filosofiämnet. De är proffs. Det känns tryggt och akademiskt oantastligt. De är de som kan ämnet bäst, de som forskar mest, som bör undervisa. Men jag tror det är fel. Jag tror att var och en av oss som arbetar som lärare ständigt behöver brottas med frågor om de yttersta skälen till varför vi - och alla dem i hela världen som vi analyserar och kommenterar - tänker, skriver, agerar som vi gör. Det innebär att vi i många fall behöver en annan förberedelse för vår undervisning än den vi redan har. Vi behöver också ett närmare samarbete mellan lärare från olika discipliner, där etiker och moralfilosofer får spela en betydligt större roll, inte i väl åtskilda kurser och kursmoment utan tillsammans i gemensamma undervisningsinslag. Och om det innebär att frågor om moral och etik, om de yttersta grunderna för våra handlingar, får en större plats i disciplinernas interna samtal via artiklar, avhandlingar och böcker, desto bättre. Sedan behöver de olika ställningstaganden som vi gör och som den omvärld vi undersöker gör, lyftas upp och diskuteras med våra studenter, inte bara i vårdvetenskap, juridik och socialt arbete där det finns ett uppenbart behov och där lärare ofta har funnit goda vägar att föra in etiska frågor i undervisningen, utan också i teknikämnena, i medieutbildningar och alla andra av våra utbildningsprogram - kanske inte minst i ekonomi.

\section{Ekonomi som religion}

Och varför nämner jag just ekonomi? För det första är det ett stort ämne. I min högskola och i många andra är företagsekonomi det största ämnet av alla, mätt

62 Aristoteles 1967, s 20. 
i antalet studenter och antalet poäng de läser. Dessutom finns ämnet överallt, vid i stort sett alla högskolor, inklusive fackhögskolorna, i Sverige och i hela västvärlden. Det är också ett populärt ämne; många ungdomar söker sig till det för att förbereda sig för alla de viktiga samhällsfunktioner som kräver en förståelse av hur ekonomiska transaktioner och system fungerar. ${ }^{63}$ Det är också ett märkvärdigt homogent ämne med i stort sett samma kurs- och utbildningsplaner på både grund- och avancerad nivå, världen över. Avvägningen mellan nationalekonomi och företagsekonomi kan vara olika men annars är stoffet väldigt stabilt både över världen och över tid.

Framförallt nämner jag ekonomi därför att ekonomi som disciplin har fått en sådan makt och inflytande $i$ hela vårt moderna samhälle. Det finns inget annat ämne som kommer i närheten - och då är det framförallt det som i Sverige kallas nationalekonomi. "Ekonomi är inte vilket akademiskt ämne som helst", skriver ekonomen Lord Robert Skidelsky och sonen, filosofen Edward Skidelsky i deras infallsrika och spännande översikt av varför människor aldrig tycks kunna få nog av pengar, och varför tillväxt och konsumtion så totalt dominerar den politiska agendan: "Det är vår tids teologi, det språk som måste talas av alla som vill få respektfull audiens i maktens boningar." ${ }^{64}$ Fram till början av 1900-talet var det filosofi som dominerade det offentliga samtalet i flera europeiska länder. I Sverige var akademiska teologer och litteraturvetare länge både smakdomare och de som förde den offentliga debatten kring landets väl. $\mathrm{Nu}$ är det mest bara nationalekonomer som göre sig besvär i större delen av västvärlden. Det finns förstås ingen annan religion som förenar oss, eller något annat sammanhängande moraliskt system som skulle kunna utgöra en bas för ett ställningstagande för eller emot. Alltså återstår tillväxten och den ekonomiska framgången.

Redan på 1990-talet började ekonomen Robert Nelson skriva om ekonomi som religion i Reaching for Heaven on Earth: the Theological Meaning of Economics, som följdes av Economics as Religion 2002. ${ }^{65}$ Där menar han att redan de tidiga ekonomerna hade en frälsningstanke bakom sina program. Genom att bättre förstå människans drivkrafter och bättre utnyttja dem kunde man frälsa människor från fattigdom, hunger och död. Nelson är i och för sig skeptisk till att ekonomernas beskrivning av människan är riktig, men han menar att

${ }^{63}$ Man kan också misstänka att det för en del är de lukrativa och därmed också statusbemängda jobben i finanssektorn som hägrar. Kanske inte så märkligt i en värld som sätter så stort värde på just finansiella transaktioner. Mitt hemlands huvudstad, London, har med deras hjälp inom några decennier förvandlats från illa skött storstad i recessionens klor till skinande rent och hypermodernt kosmopolitiskt finans- och kulturcentrum, hett eftertraktad av Europas och världens ungdom.

64 "Economics is not just any academic discipline. It is the theology of our age, the language that all interests, high and low, must speak if they are to win a respectful hearing in the courts of power." Skidelsky $2012 \mathrm{~s} 92$.

${ }^{65}$ Nelson 1993, Nelson 2002. Titlarna på två av avsnitten i den senare boken ger ett smakprov på hans resonemang: "Part One: The laws of economics as the new word of God/.../Part Three: The Gods of Chicago". 
den har varit så värdefull som religion därför att den bevisligen fört miljontals människor ur fattigdom och elände. Som religion bygger den på en förståelse av människan som konkurrerande och egennyttigt vinstmaximerande till sin innersta natur. Ju flera områden i samhället som anpassas till marknadsmänniskan desto bättre. Och detta är en trossats som också i hög grad påverkat inte minst Sverige de senaste decennierna genom införandet av mer eller mindre artificiella marknader på alltfler områden som tidigare varit en gemensam uppgift för samhället. I sin svidande uppgörelse med "den ekonomiske mannen" i Det enda könet skriver Katrine Kielos att "...idén om att marknadens logik bor i människans natur är en föreställning som vi lever med varje dag. Den har trängt djupare och djupare in i kulturen. Vi uppmanas att vända oss till den om och om igen, och på allt fler områden...Det vi kallar ekonomisk teori är idag den formella versionen av den dominerande världsbilden. Vår tids stora berättelse: vilka vi är, varför vi är här och anledningen till att vi gör som vi gör.”6 Och, skriver Kielos, den ekonomiske mannens "definierande karaktäristik är att han inte är kvinna".

Just när jag skriver detta, i maj 2014, har det kommit en protest från studenter i ämnet vid Manchester University, ett upprop som snabbt vunnit stöd av studentföreningar runtom i världen. Economics, Education and Unlearning. Economics Education at the University of Manchester heter den lilla skriften. Den är märkvärdig på flera sätt. Dels för att studenterna själva systematiskt och välformulerat utövar sin rätt - sin skyldighet skulle jag egentligen vilja säga - att ifrågasätta ett standardinnehåll $i$ kurserna. Kurserna domineras helt av den så kallade nyklassiska teoribildningen och tillåter ingen diskussion av alternativa ekonomiska modeller, vare sig feministiska, post-Keynsianska, ekologiska eller vad det månde vara och dödar därmed varje försök till kritiskt, självständigt tänkande. Etiska frågor lyser helt med sin frånvaro liksom historiska perspektiv, skriver studenterna. De efterfrågar en mycket större mångfald av kritiska perspektiv och begär att nationalekonomi som ämne lever upp till Manchesteruniversitetets stolta ambitioner "att förbereda studenter för medborgarskap och ledarskap i skiftande globala miljöer". Intressant nog, med tanke på ett resonemang jag för på flera andra ställen om det premiebaserade kvalitetsarbetets fördärvliga inflytande på allt snävare discipliner, lägger de en del av skulden för det rättläriga innehållet hos ett bibliometriskt fördelningssystem för forskningsresurser. De ekonomitidskrifter som är högst rankade och ger störst utdelning till universitetet i form av forskningsmedel är de som trognast avspeglar de nyklassiska idealen. Därför rekryterar universitetet bara sådana lärare som kommer att få artiklar publicerade i dessa tidskrifter.

Skriften är också märkvärdig för att den inleds av ett förord av ingen mindre än chefsekonomen vid Bank of England, Andrew Haldane. Haldane pekar på hur illa den smala tillämpningen av nyklassisk ekonomisk teori har tjänat samhället. Det vore bättre, menar han att överge det snäva hyllandet av vinstjakten

\footnotetext{
66 Kielos 2012, s 246-7.
} 
byggd på konkurrens och komplettera med en bild av människan som samarbetsinriktad med ömsesidig rättvisa som vägledande princip. Ekonomiska institutioner i landet behöver unga människor som kan se utvecklingen i en mångfald av perspektiv, inte minst historiska. Med ett sådant inflytelserikt stöd kan man hoppas att uppropet vinner framgång. Men eftersom systemet för forskningsfinansiering är som det är, kan det dröja.

Efter att ha försökt reda ut vad rättvisa egentligen innebär och hur orättvisan och ojämlikheten de senaste trettio åren ökat inom våra västerländska samhällen, så till den grad att den håller på att spränga dem, gav jag här mig i kast med att diskutera grunderna för vad ett gott liv kan vara och hur vi borde agera för att leva ett sådant. Min slutsats i båda dessa frågor är att de behöver en grundlig och återkommande diskussion $i$ alla högskolans utbildningar och även i dess forskning, för att vi som deltar, vare sig som lärare eller student, ska ha en chans att förstå och hantera den snabbt föränderliga och ofta förvirrande värld vi lever i. Ett exempel på ett sådant område som tycks ha överlämnat frågor om rättvisa och moral med varm hand till andra är ekonomutbildningar världen över. Ekonomilärarna och de studenter de för in i ekonomins tankevärld skulle kunna lämna ett kraftfullt stöd för att förstå och i förlängningen kunna förändra en värld som står inför enorma utmaningar. Få verkar göra det idag. På grundval av egna växande moraliska insikter, byggda från första principer, behöver därför studenter delta i en medveten diskussion om de globala ekonomiska, ekologiska och sociala utmaningarna. Förmodligen finns inte något bättre ställe än högskolan, med dess tillgång till alla världens data och analyser, att föra en sådan diskussion. 